\title{
NUTRITIVE VALUE OF SUN-DRIED GRAPE POMACE, INCORPORATED AT A LOW LEVEL IN COMPLETE FEED FOR THE RABBIT BRED UNDER MAGREBIAN CONDITIONS
}

\author{
Guemour D.*, Bannelier C. ${ }^{\dagger \neq,}$, Dellal A.., Gidenne T. ${ }^{\dagger \neq, \&}$ \\ *Université d'Ibn-Khaldoun, BP 78. 14000 TIARET. Algeria. \\ INRA, UMR1289 Tissus Animaux Nutrition Digestion Ecosystème et Métabolisme. 31326 CASTANET-Tolosan. France. \\ Université de Toulouse, INPT ENSAT, UMR1289 Tissus Animaux Nutrition Digestion Ecosystème et Métabolisme. \\ 31326 Castanet-Tolosan. France. \\ ${ }^{\S}$ ENVT, UMR1289 Tissus Animaux Nutrition Digestion Ecosystème et Métabolisme. 31076 Toulouse. France. \\ \#Université d'Ibn-Khaldoun, Laboratoire d'Agro-Biotechnologie et de Nutrition en Zone Semi-arides, BP 78. \\ 14000 TIARET. Algeria.
}

\begin{abstract}
Aвstract: The nutritive value and potential use of sun-dried grape pomace ( $\mathrm{g} / \mathrm{kg}$ as fed: 140 of crude protein (CP), 529 of neutral detergent fibre (NDF), 460 acid detergent fibre, 293 acid detergent lignin) for fattening rabbits was studied by comparing 3 experimental diets containing a low but increasing incorporation rate of grape pomace (GP): $0 \%$ (control, GP0), 3\% (GP3), and 6\% (GP6) in substitution to the control diet (251 g NDF and $175 \mathrm{~g} \mathrm{CP} / \mathrm{kg}$ ) formulated with raw materials available in the area of Tiaret (Algeria): barley, wheat bran and straw, soybean meal and faba bean. Three groups of 30 rabbits (individually caged) were fed ad libitum the three diets from weaning ( $35 \mathrm{~d}$, mean weight $460 \pm 83$ g) to $77 \mathrm{~d}$ of age. The dry matter digestibility was obtained from total and individual faecal collection on all animals ( 3 $x$ 30), during four consecutive days each week from 42 to $77 \mathrm{~d}$ of age. Then, faeces from 10 rabbits per group were selected for nutrient analyses. Intake and weight gain were recorded twice a week during the whole fattening period. Incorporating 3 or $6 \%$ of GP in a low fibre diet impaired from 35 to $77 \mathrm{~d}$ growth rate (-8.8\% for GP3 and GP6 vs. GP0, $P<0.01)$, feed conversion ( $+8.5 \%$ for GP6 vs. GP0, $P<0.01)$, and dressing out percentage $(-2.5 \%$ for GP3 and GP6 vs. GP0, $P<0.001)$. The digestibility of organic matter was linearly reduced from 72.8 to $70.0 \%$ with the GP incorporation rate $(P<0.01)$, while crude protein digestibility remained unaffected and averaged $78.7 \%$. The predicted nutritive value of sun-dried GP calculated by regression was high but highly variable for digestible energy $(9.33 \pm 2.01 \mathrm{MJ} \mathrm{DE} / \mathrm{Kg}$, raw basis), and particularly for the digestible protein content $(81.8 \pm 77.2 \mathrm{~g} \mathrm{DCP} / \mathrm{kg})$. Thus, the sun-dried whole grape pomace could be considered as an alternative fibre source for the rabbit feeding in Magrebian area.
\end{abstract}

Key Words: rabbit, grape pomace, growth, nutritive value.

\section{INTRODUCTION}

Valorisation of agricultural by-products in animal feeding provides new low-cost raw materials for animal feeding. It is especially interesting for fibrous feedstuffs due its limited availability for rabbit diets in many countries. Its use also contributes to reduce the vegetal wastes and to protect environment. For instance, in the Algerian context, grape producers reject large quantities of grape marc (in 2005, about

Correspondence: T. Gidenne, thierry.gidenne@toulouse.inra.fr Received May 2009 - Accepted February 2010 
$1500 \mathrm{t}$ for the west region of Algeria). Because of the high water content of the grape pomace (GP) a drying process is necessary to store this raw material and allow a further use in animal feeding. In the Magrebian area, a low cost, effective and simple process consist simply to dry the product under the sun. Since the grape marc is a product readily available in large quantities in the west regions of Algeria, it could be used for animal feeding, and particularly for herbivorous, since this type of raw material is known to for its high tannin, fibre and lignin concentration (FEDNA, 2003; INRA, 2004). Therefore, this product could be an interesting source of fibre and lignin, particularly for the rabbit feeds for which fibre sources are difficult to obtain by feed manufacturers in Magrebian area. In addition, this type of products is classically used at low incorporation levels in pelleted feeds, essentially to limit potential adverse effects on growth. However, the digestible energy (DE) value of the GP, produced in Europe and dried by heating, for the growing rabbit is highly variable, and could range from 1.67 (Martínez and Fernández, 1980) to $7.61 \mathrm{DE} \mathrm{MJ} / \mathrm{kg}$ (Motta Ferreira et al., 1996), being this difference partially explained by the method used to determine nutritive value (Villamide et al., 2003). Furthermore, the drying process may modify the nutritive value of the product. This study thus aimed to estimate the nutritive value of sundried GP, for low dietary incorporation rates. We also aimed to describe the effects of sun-dried GP on intake and growth for the rabbit bred under Magrebian context.

\section{MATERIALS AND METHODS}

\section{Experimental design and feeds}

The trial was conducted during August and September 2006 in the rabbit unit (farm mean temperature ranging from 28 to $34^{\circ} \mathrm{C}$ ) of the experimental farm of the Faculty of Agronomic and Veterinary Sciences (University of Tiaret, Algeria). Chemical analyses were conducted at INRA of Toulouse (UMR 1289 TANDEM).

One batch of whole grape pomace was collected from one cave ("Wilis", Mostaganem, west Algeria) and sun-dried for $7 \mathrm{~d}$. The grape pomace was obtained from a mixture of four varieties of grapes (Cinsault, Carignan, Alicante and Grenache). A total of $600 \mathrm{~kg}$ of whole grape pomace was sun-dried to obtain 270 $\mathrm{kg}$ of dried grape pomace containing $9 \%$ of water. The composition of this product was reported in the Table 1. Three experimental pelleted feeds containing an increasing incorporation rate of grape marc were

Table 1: Chemical composition of the sun-dried grape pomace and comparison with values found for heatdried grape pomace in some feedstuffs tables.

\begin{tabular}{lcccc}
\hline g/kg as raw basis & $\begin{array}{c}\text { Grape pomace } \\
\text { sun-dried }^{1}\end{array}$ & $\begin{array}{c}\text { EGRAN }^{2} \\
(2002)\end{array}$ & $\begin{array}{c}\text { FEDNA } \\
(2003)\end{array}$ & $\begin{array}{c}\text { INRA } \\
(2004)\end{array}$ \\
\hline Dry matter & 908 & 918 & 918 & 918 \\
Crude ash & 111 & 83 & 58 & 84 \\
Crude protein $(\mathrm{N} \times 6.25)$ & 140 & 119 & 112 & 131 \\
Neutral detergent fibre & 529 & 571 & 571 & 571 \\
Acid detergent fibre & 460 & 490 & 505 & 481 \\
Acid detergent lignin & 293 & 306 & 315 & 322 \\
Digestible protein & - & 0 & 80 & 0 \\
Gross energy, $\mathrm{MJ} / \mathrm{kg}$ & 15.96 & - & - & 17.28 \\
Digestible energy, $\mathrm{MJ} / \mathrm{kg}$ & - & 5.12 & 3.77 & 5.10 \\
\hline
\end{tabular}

${ }^{1}$ Used in the present study. ${ }^{2}$ Maertens et al. (2002). 
Table 2: Ingredient and chemical composition of experimental diets.

\begin{tabular}{lccc}
\hline Ingredient, \% as fed & GPO & GP3 & GP6 \\
\hline Grape pomace sun-dried & 0 & 3 & 6 \\
Barley & 26.00 & 25.20 & 24.39 \\
Wheat bran & 44.00 & 42.64 & 41.28 \\
Soybean meal & 15.00 & 14.54 & 14.07 \\
Faba bean & 2.00 & 1.94 & 1.88 \\
Wheat straw & 10.00 & 9.69 & 9.38 \\
DL-Methionin & 0.54 & 0.54 & 0.54 \\
Sodium chloride & 1.00 & 1.00 & 1.00 \\
Vitamin/mineral premix ${ }^{1}$ & 1.46 & 1.46 & 1.46 \\
Chemical composition, $\mathrm{g} / \mathrm{kg}$, as raw basis & & & \\
$\quad$ Dry matter & 918 & 919 & 920 \\
Crude ash & 72 & 64 & 69 \\
Crude protein $(\mathrm{N} \times 6.25)$ & 175 & 169 & 176 \\
$\quad$ Neutral detergent fibre & 251 & 269 & 279 \\
$\quad$ Acid detergent fibre & 82 & 101 & 104 \\
Acid detergent lignin & 18 & 33 & 33 \\
Gross energy, MJ/kg & 15.30 & 15.59 & 15.58 \\
\hline
\end{tabular}

${ }^{1}$ Provided by Bouhzila S. A (Sétif, Algeria). Mineral and vitamin composition (g/kg premix): Se, 0.025; Mg, 5; Mn, 7.5; Zn, 7.5; I, 0.12; Fe, 3.6; $\mathrm{Cu}, 2.25 ; \mathrm{Co}, 0.04$; thiamin, 0.1; riboflavin, 0.45 ; calcium d-pantothenate, 0.6; pyridoxine, 0.15; biotin, 0.0015 ; nicotinic acid, 2; choline chloride, 35; folic acid, 0.4; vitamin $\mathrm{K}_{3}, 0.2$; dl- $\alpha$-tocopheryl acetate, 1.35; biotin, 0.0015; folic acid, 0.04; cyanocobalamin, 0.0006; vitamin A, 850000 IU; vitamin D3, 170000 IU.

prepared by substituting the basal diet, without minerals and premix, with 0,3 or $6 \%$ of grape marc (GP0, GP3, GP6, respectively; Table 2). Mineral and premix were added to all diets at a fixed amount of 3\%. The basal mixture was prepared with feedstuffs available in the area of Tiaret, and formulated to reach a level of protein close to recommendations (Table 2, Gidenne, 2000; Lebas, 2004). However, following the substitution method to determine the nutritive value of an ingredient, the chemical composition of the feeds were not balanced for the incorporation of sun-dried GP. Since fibre sources were scarce in this area, a basal mixture with low fibre levels was formulated (about 10\% ADF), in comparison to levels recommended in European conditions to reduce the risk of digestive troubles (Gidenne, 2003). No antibiotics were added to the feeds or in the water.

\section{Animals and Measurements}

A total of 90 rabbits, belonging to the local Algerian population (Zerrouki et al., 2005, 2007; LakabiIoualitene et al., 2008), were weaned and allotted at $35 \mathrm{~d}$ of age (mean weight: $460 \pm 83 \mathrm{~g}$ ), to the three experimental diets $(30 / \mathrm{diet})$. They were bred in individual wired metabolism cages $(56 \times 38 \times 28 \mathrm{~cm})$ till $77 \mathrm{~d}$ old. Water and experimental diets were given ad libitum from weaning (35 d) to slaughter (77 d).

To obtain a higher precision in the measure of the dry matter digestibility, and thus to compensate the low incorporation rate of the grape marc in the feed (Villamide, 1996), the faeces were collected totally and individually from 42 to $77 \mathrm{~d}$ old, each week during 4 consecutive days. Then the faeces were dried and weighed and dry matter (DM) digestibility was calculated individually for all animals (30/diet), 
Table 3: Effect of grape pomace (GP) dietary level ${ }^{1}$ on feed intake and growth of rabbits.

\begin{tabular}{|c|c|c|c|c|c|}
\hline Experimental diets & GP0 & GP3 & GP6 & $\mathrm{SEM}^{2}$ & $P$-value \\
\hline No. & 25 & 24 & 24 & & \\
\hline \multicolumn{6}{|l|}{ Period $35-49 \mathrm{~d}$} \\
\hline Live weight at $35 \mathrm{~d}$ (weaning), $\mathrm{g}$ & 477 & 470 & 424 & 93 & 0.013 \\
\hline Live weight at $49 \mathrm{~d}^{3,4} \mathrm{~g}$ & $757^{\text {a }}$ & $732^{\mathrm{ab}}$ & $706^{\mathrm{b}}$ & 13 & 0.020 \\
\hline Daily weight gain, g/d & 21.1 & 19.4 & 18.4 & 0.88 & 0.093 \\
\hline Daily intake, $g / d$ & $48.5^{\mathrm{a}}$ & $41.9^{b}$ & $43.8^{\mathrm{b}}$ & 1.28 & 0.002 \\
\hline Feed conversion, g/g & 2.38 & 2.26 & 2.44 & 0.091 & 0.43 \\
\hline \multicolumn{6}{|l|}{ Period 49-77 d } \\
\hline Live weight at $77 \mathrm{~d}$ (slaughter), $\mathrm{g}$ & $1447^{\text {a }}$ & $1330^{\mathrm{b}}$ & $1339^{b}$ & 20 & $<0.001$ \\
\hline Daily weight gain, $g / d$ & $24.9^{\mathrm{a}}$ & $21.5^{b}$ & $22.2^{\mathrm{ab}}$ & 0.62 & $<0.001$ \\
\hline Daily intake, $g / d$ & $79.3^{\mathrm{a}}$ & $73.2^{b}$ & $78.2^{\mathrm{a}}$ & 1.38 & 0.006 \\
\hline Feed conversion ${ }^{5}, \mathrm{~g} / \mathrm{g}$ & $3.23^{\mathrm{a}}$ & $3.42^{\mathrm{ab}}$ & $3.55^{\mathrm{b}}$ & 0.074 & 0.012 \\
\hline \multicolumn{6}{|l|}{ Period $35-77 \mathrm{~d}$} \\
\hline Daily weight gain, g/d & $23.6^{\mathrm{a}}$ & $20.8^{b}$ & $20.9^{\mathrm{b}}$ & 0.48 & $<0.001$ \\
\hline Daily intake, $g / d$ & $69.0^{\mathrm{a}}$ & $62.8^{b}$ & $66.7^{\mathrm{ab}}$ & 1.15 & 0.001 \\
\hline Feed conversion ${ }^{5}, \mathrm{~g} / \mathrm{g}$ & $2.95^{\mathrm{a}}$ & $3.03^{\mathrm{ab}}$ & $3.20^{\mathrm{b}}$ & 0.056 & 0.007 \\
\hline Dressing out percentage $e^{4,5} \%$ & $57.9^{\mathrm{a}}$ & $56.0^{\mathrm{b}}$ & $55.3^{\mathrm{b}}$ & 0.42 & $<0.001$ \\
\hline
\end{tabular}

${ }^{1} \mathrm{GP} 0$ : experimental diet with $0 \%$ of grape pomade, GP3: experimental diet with $3 \%$ of grape pomade, GP6: experimental diet with $6 \%$ of grape pomade. ${ }^{2}$ SEM: standard error of the mean. ${ }^{3}$ Weights at 49 and $77 \mathrm{~d}$ were analysed according to the covariate "weight at $35 \mathrm{~d}$ ", and least square means are presented. ${ }^{4}$ Eviscerated carcass, but with liver, heart, lungs, kidney, head and extremities without sleeves; weighed $15 \mathrm{~min}$ after the slaughter. ${ }^{5}$ Significant linear effect $(P<0.05)$ of level of inclusion of GP.

Mean values in the same row with a different superscript differ at $P<0.05$.

as proposed by Perez et al. (1995). Thus, the digestibility coefficients corresponded to the mean value measured on the $42-77 \mathrm{~d}$ period. Then for each group, ten samples of faeces centered on the mean DM digestibility of the group, were selected for nutrient analyses (crude protein (CP), gross energy, ash, neutral detergent fibre (NDF) and acid detergent fibre (ADF)). Intake and weight gain were registered twice a week from 35 to $77 \mathrm{~d}$, while the health status was checked daily. At slaughter, the hot carcass was weighed after evisceration, but with liver, heart, lungs, kidney, head and extremities without sleeves. The chemical analyses were performed at INRA (UMR 1289 TANDEM) on diets, faeces (10 per group) and on the grape pomace studied, according to ISO methods and considering the recommendations proposed by the EGRAN group (EGRAN, 2001): dry matter (ISO 6496:1999), crude ash (ISO 5984:2002), crude protein $(\mathrm{N} \times 6.25$, Dumas method, ISO 16634-2:2009), energy (ISO 9831:1998) and fibres (NDF, ADF and acid detergent lignin (ADL)) according to sequential method of Van Soest (AFNOR 1997, ISO 16472:2006 and ISO 13906:2008).

\section{Statistical analyses}

Data were analyzed as a completely randomized design with type of diet as the main source of variation by using the GLM procedure of SAS software (OnlineDoc ${ }^{\circledR}$, SAS Inst., Cary, NC). Means comparison were done by using the test of Scheffe. However, since at weaning the live weights were relatively variable and almost different between GP6 and the two other groups (Table 3), a covariance analysis for the weights at $49 \mathrm{~d}$ and at slaughter ( $77 \mathrm{~d}$ ) was performed. In addition, the linear effect of GP incorporation was analysed 
with the REG procedure of SAS. The nutritive value of grape pomace has been calculated according to the regression method described by Villamide et al. (2001).

\section{RESULTS AND DISCUSSION}

\section{Grape pomace composition and experimental feeds}

The grape pomace (GP) has a high cell-wall content and a high concentration in klason lignin. Besides, it has an appreciable amount of condensed tannins $(21 \mathrm{~g} / \mathrm{kg} \mathrm{DM})$ and phenolic tannin $(45 \mathrm{~g} / \mathrm{kg} \mathrm{DM}$; Baumgärtel et al., 2007) that could lead to overestimation of lignins according to the sequential Van-Soest procedure (Van-Soest et al., 1991). The comparison of the FEDNA and INRA tables (Table 1) indicated that the grape pomace is a by-product with a large variability in its chemical composition (e.g. for ash or protein content), but also in the estimated values for digestible energy (3.77 to $5.12 \mathrm{MJ} / \mathrm{kg}$ ) and more particularly for digestible protein $(0$ to $80 \mathrm{~g} / \mathrm{kg})$. The chemical analysis of our grape pomace (Table 1$)$ gave values close to those INRA tables (2004), except a higher value for crude ash $(+30 \%)$ that partially explained the lower value for gross energy $(-8 \%)$. The level of crude protein was also higher but remained close $(+8.4 \%)$ to the product mentioned in the INRA tables (2004). These moderate discrepancies among the values reported in feeds tables and our product ranged within classical variations reported by previous authors (Fraga et al., 1991; Fernández-Carmona et al., 1996; Motta Ferreira et al., 1996), and associated with the variety of pressed grape, agricultural conditions, and technological treatment of the pomace (Carabaño and Fraga, 1992).

A moderate incorporation of grape pomace in the feed increased the NDF and ADF concentration (Table 2), but more especially that of ADL, since it is the main interest of this product: to provide lignin in order to cover the requirements for the growing rabbit (Nicodemus et al., 1999; Gidenne et al., 2001). In return, the concentration in crude protein remained similar among the three experimental feeds. In fact, compared to the grape pomace studied by Fraga et al. (1991) or by Motta Ferreira et al. (1996), our product contained higher amount of crude protein (14\%) and lower amount of NDF or ADF.

\section{Health status, intake and growth of animals}

Since our feeds were not balanced for GP incorporation, this trial was not properly designed to evaluate the effects of sun-dried GP on rabbit performance and health. However, our results supplied some valuable information for further experiments in this area. Globally, throughout the experiment, the health status of rabbits was relatively good since only 14 rabbits died out of 90 (no antibiotic treatment during the trial), and no effect of the diet was detectable (4/30, 5/30, 5/30 for GP0, GP3 and GP6 respectively).

The moderate incorporation of grape pomace ( 3 to $6 \%$ ) linearly decreased the live weight $(P=0.02$; Table 3) two weeks after weaning ( $-6.7 \%$ from 0 to $6 \%$ incorporation of GP). This is associated to a $11.6 \%$ lower feed intake for feeds containing grape pomace $(P<0.05)$, although their NDF content was higher. Consequently, the post-weaning feed conversion did not differ significantly among the groups. This highlights a potential negative effect of GP incorporation possibly due to appetency problems for the young rabbit after weaning. In return, during the finishing growing period (49-77 d), rabbits fed GP3 diet had a lower feed intake and growth rate compared to GP0 $(P<0.05)$, while animals fed the GP6 diet showed a similar feed intake than GP0 diet but an intermediate growth rate between GP3 and GP0. As a consequence, the feed conversion increased linearly $(P<0.05)$ with GP incorporation from 49 to $77 \mathrm{~d}$ of age. For the whole fattening period, the growth rate was only $9 \%$ lower with feeds containing the GP $(P<0.05)$, indicating a global impairment effect on rabbit growth for the sun-dried grape pomace, even at a low level of incorporation. The feed conversion increased linearly $(P<0.05)$ with GP level. It seems logical taking into account the higher fibre level of GP diets and their lower nutrient digestibility (Table 
Table 4: Effect of grape pomace (GP) dietary level ${ }^{1}$ on faecal digestibility coefficients (\%) and nutritive value of experimental diets in growing rabbits between 42 and $77 \mathrm{~d}$ of age.

\begin{tabular}{|c|c|c|c|c|c|}
\hline Experimental diets & GP0 & GP3 & GP6 & $\mathrm{SEM}^{2}$ & $P$-value \\
\hline \multicolumn{6}{|l|}{ Digestibility coefficients (\%) } \\
\hline Dry matter $(\mathrm{DM})^{3}$ & $72.7^{\mathrm{a}}$ & $72.0^{\mathrm{a}}$ & $69.9^{\mathrm{b}}$ & 0.26 & $<0.001$ \\
\hline Organic matter $(\mathrm{OM})^{3}$ & $72.8^{\mathrm{a}}$ & $72.0^{\mathrm{a}}$ & $70.0^{\mathrm{b}}$ & 0.25 & $<0.001$ \\
\hline Energy & $71.7^{\mathrm{a}}$ & $71.6^{\mathrm{a}}$ & $69.8^{\mathrm{b}}$ & 0.29 & 0.001 \\
\hline Crude protein & $78.6^{\mathrm{ab}}$ & $79.3^{\mathrm{a}}$ & $76.5^{\mathrm{b}}$ & 0.74 & 0.037 \\
\hline Neutral detergent fibre & 34.6 & 36.0 & 32.6 & 0.97 & 0.057 \\
\hline Acid detergent fibre & 13.6 & 14.4 & 12.4 & 1.24 & NS \\
\hline $\mathrm{NNCC}^{4,5}$ & 93.2 & 93.2 & 93.5 & 0.46 & 0.094 \\
\hline \multicolumn{6}{|l|}{ Dietary nutritive value } \\
\hline DP $(\mathrm{g} / \mathrm{kg} \text { raw basis })^{6}$ & 137 & 134 & 134 & 0.13 & 0.12 \\
\hline $\mathrm{DE}(\mathrm{MJ} / \mathrm{kg} \text { raw basis })^{7}$ & $10.98^{\mathrm{b}}$ & $11.18^{\mathrm{a}}$ & $10.89^{\mathrm{b}}$ & 0.04 & 0.002 \\
\hline Ratio DP/DE (g/MJ, raw basis) & $12.62^{\mathrm{b}}$ & $12.04^{\mathrm{a}}$ & $12.50^{\mathrm{b}}$ & 0.09 & 0.018 \\
\hline
\end{tabular}

${ }^{1} \mathrm{GP} 0$ : experimental diet with $0 \%$ of grape pomade, GP3: experimental diet with $3 \%$ of grape pomade, GP6: experimental diet with $6 \%$ of grape pomade. ${ }^{2}$ SEM: standard error of mean. ${ }^{3}$ Number of rabbits at the end of the experimental period for DM and OM digestibility were 26, 25 and 25 for GP0, GP3, GP6 respectively. Means from 10 samples per group selected for chemical analyses. ${ }^{4} \mathrm{NNCC}$ (non nitrogenous cellular content) $=\mathrm{OM}-\mathrm{CP}-\mathrm{NDF} .{ }^{5}$ Significant linear effect $(P<0.05)$ of level of inclusion of GP. ${ }^{6} \mathrm{DP}$ : digestible crude protein. ${ }^{7} \mathrm{DE}$ : digestible energy.

Mean values in the same row with a different superscript differ, $P<0.05$; NS: $P>0.15$.

4). Similarly, Schurg et al. (1980) reported an increase in feed conversion, but for higher GP incorporation rates $(5-50 \%)$. Besides, we detected also a negative linear impact $(P<0.05)$ of the GP on the dressing out percentage, that may originate in the higher fibre content of the GP3 and GP6 feeds. This effect of GP on dressing out percentage should be confirmed with balanced diets not differing in chemical composition but containing increasing GP levels.

\section{Nutritive value of the grape pomace}

Let us recall that we choose to evaluate the nutritive value of GP for low incorporation rates in the feed that are the most probable rates for the feed industry. Obviously, as described by Villamide (1996) and Villamide et al. (2001) the incorporation of feed ingredients at a low level $(<10 \%)$ leads to a lower precision in the estimated nutritive value, particularly if measured on a low number of animals and on a short period ( $4 \mathrm{~d}$ as recommended by Perez et al., 1995). Thus, we tried to compensate it by measuring on a high number of animals and by a longer period of measurement (42 to $77 \mathrm{~d}$ ), to obtain a mean nutritive value for the whole growth period after a two weeks of adaptation. In fact, we obtained a low variability in the measurement of dietary DM and organic matter (OM) digestibility (coefficient of variation of 2.7 and $1.1 \%$ respectively), supporting the good precision of these measurements, similar to those obtained in more standardised environment such in European research units.

Since the grape pomace has a high concentration in lignin (Table 1), the dietary NDF and ADL level increased sharply with GP incorporation (Table 2), and could explain the negative effect on digestive efficiency for DM, OM or energy (Table 4, Gidenne and Perez, 1994). However, the negative effect of GP on protein and energy digestion appeared significant only for a $6 \%$ incorporation rate. For instance, decrease in CP digestibility was previously observed in rabbits using GP, but with diets containing higher GP levels (Martínez and Fernández, 1980; Parigi-Bini and Chiericato, 1980; Maertens and de 


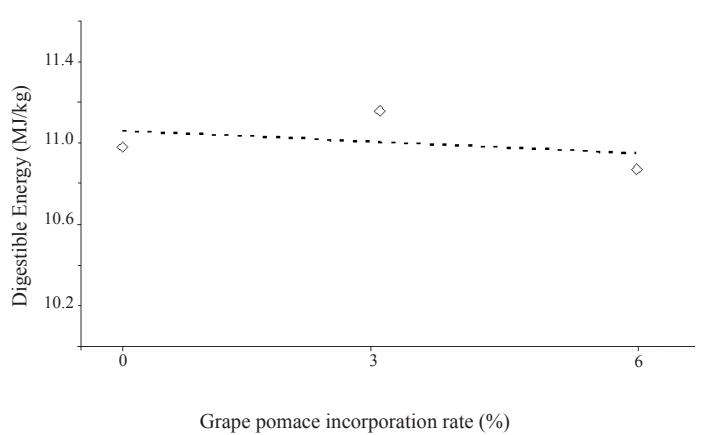

Figure 1: Digestible energy (DE) concentration of experimental diets according to the grape pomace $(\mathrm{GP})$ incorporation rate $[\mathrm{DE}(\mathrm{MJ} / \mathrm{kg})=11.054-0,0172$ GP (\%); rsd $=0.043 ; \mathrm{R}^{2}=0.085 ; P<0.001, P=0,29$ for slope and intercept respectively].

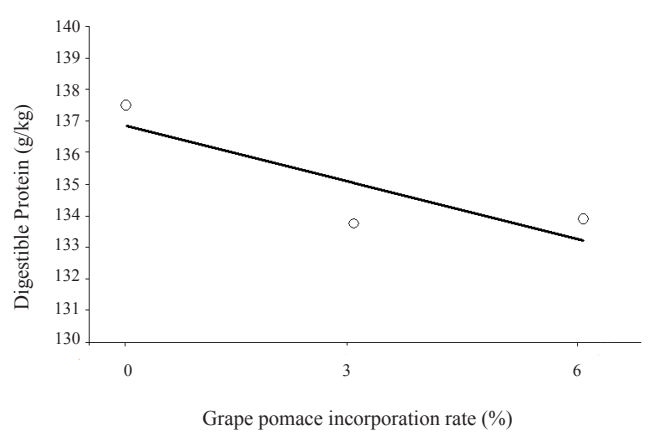

Figure 2: Digestible protein (DP) concentration of experimental diets according to the grape pomace (GP) incorporation rate $[\mathrm{DP}(\mathrm{g} / \mathrm{kg})=136,8-0,55 \mathrm{GP}$ $(\%) ; \mathrm{rsd}=0.079 ; \mathrm{R}^{2}=0.110 ; P=0.078, P<0.001$ for slope and intercept respectively].

Groote, 1984; Pérez de Ayala et al., 1991; Motta Ferreira et al., 1996). Thus, effect of grape pomace on rabbit digestion seemed to be largely modulated by their dietary incorporation rate. It is in agreement with literature, since grape pomace is characterized for its high content in tannins, and complexes with dietary proteins are formed and led to a lower digestion. Also, the proteolytic and fibrolytic capacity of micro-organisms could be impaired, as shown for ruminants (Waghom et al., 1987; Magnier, 1991) that contributes to reduce the feed efficiency.

Using the digestibility coefficient for energy and protein obtained on the three feeds, we obtained the equation to predict by the regression method the digestible energy and protein of sun-dried grape pomace (Figures 1 and 2). Accordingly, and using the calculation procedure proposed by Villamide et al. (2001), the digestible energy concentration of the sun-dried grape pomace reached a value of $9.33 \pm 2.01 \mathrm{MJ} /$ $\mathrm{kg}$ (raw basis, Figure 1). Using the difference calculation method, with diets GP0 and GP6, we found a similar value of $9.23 \mathrm{MJ} / \mathrm{kg}$. The energetic value of our sun-dried grape pomace was $2 \mathrm{MJ}$ over that proposed by Motta Ferreira et al. (1996) for a more fibrous GP (58.2 vs. 63.2 \% NDF, and 32.2 vs. $37.4 \%$ ADL, on DM basis), and even higher than those proposed in tables: from 3.08 (Maertens and De Groote, 1984) to $5.12 \mathrm{MJ} / \mathrm{kg}$ (EGRAN tables, Maertens et al., 2002; see also Table 1). The standard error for the predicted value was here relatively high $\pm 2.01 \mathrm{MJ} / \mathrm{kg}(22 \%)$, mainly because the GP incorporation rate was low (Villamide, 1996). Nevertheless, we assumed that our product presented a higher energetic value than usually proposed, since its proteic content was higher and its fibre content was lower than in current European tables of ingredients. Moreover, we used a low incorporation level in the feed (close to the common practice) that probably avoid any major antinutritionnal effect from tannins or other components. Besides, previous studies on the grape pomace also reported high variability in estimating the energetic content even for higher incorporation rates (Motta Ferreira et al., 1996).

Similarly, the digestible protein content (DPC) of the sun-dried GP reached a relatively high level of $81.8 \pm 77.2 \mathrm{~g} \mathrm{DCP} / \mathrm{kg}$ (see equation on Figure 2), that was similar to the value proposed in FEDNA tables (2003). However, our estimation was associated to a high standard error for the predicted value, since few variations of protein digestibility were here registered and since we choose to estimate the GP value for low incorporation rate (as used in practical conditions). Using the difference calculation method (between GP0 and GP6), the DCP content of the sun-dried GP was quite similar: $78.9 \mathrm{~g} \mathrm{DCP} / \mathrm{kg}$. Likewise for energy, the literature for the digestible protein content of grape pomace is not consistent, although 
frequently the incorporation of grape pomace led to a significant decrease of protein digestion, but for higher incorporation rates than here.

Besides, we should also consider than our control experimental feed contained a low level of fibre respect to classical European recommendations. Such differences may influence the digestive processes in the rabbit and thus the nutritive value of our grape pomace (De Blas and Villamide, 1990; De Blas and Carabaño, 1996).

Nevertheless, a possible overestimation of the nutritive value was possible (high standard error of the predicted value) since the risk of error is increased for low incorporation rates from mathematical reasons and also because the impact of the basal mixture is high. But, differences with European tables may also be due to the variety of grape, the technology for juice extraction (skins stems and seeds) and the drying treatment of the grape pomace. For instance, the sun-drying allows a low-temperature process compared to dehydratation in oven. Consequently, the potential concentration of complexes among sugars and proteins or with tannins should be lower. Accordingly, alfalfa dehydrated at low temperature allows a higher protein digestibility compared to the same product dehydrated at a high temperature in an oven (Lebas and Goby, 2005). These differences might be also due to the method used to determine nutritive value (Villamide et al., 2003).

\section{CONCLUSION}

The nutritive value obtained in the present work for the sun dried grape pomace was high $(9.33 \pm 2.01 \mathrm{MJ}$ $\mathrm{DE} / \mathrm{kg}$ and $81.8 \pm 77.2 \mathrm{~g} \mathrm{DCP} / \mathrm{kg}$ ) compared to the literature. Whole grape pomace can be considered as alternative cheap fibre source for the growing rabbit, in our Magrebian area, since no major adverse effects on growth or health were found, for low incorporation level (about 5\%). However, further experiments are necessary to confirm the present results and try to determine the maximum incorporation rates for the sun-dried grape pomace in balance feeds.

Acknowledgements: The authors thank Muriel Segura and Véronique Tartié (INRA Toulouse UMR 1289 TANDEM) for their help in biochemical analyses.

\section{REFERENCES}

AFNOR. 1997. Norme Française homologuée, Aliments des animaux. Détermination séquentielle des constituants pariétaux. Méthode par traitement aux détergents neutre et acide et à l'acide sulfurique. AFNOR publ., Paris. NF V 18-122, pp 11 .

Baumgärtel T., Kluth H., Epperlein K., Rodehutscord M., 2007. A note on digestibility and energy value for sheep of different grape pomace. Small Ruminant Res., 67: 302-306.

Carabaño R., Fraga M.J. 1992. The use of local feeds for rabbits. Options Méditerranéennes. Série Séminaires, 17: 141-158.

De Blas C., Villamide M.J. 1990. Nutritive value of beet and citrus pulp for rabbits. Anim. Feed Sci. Technol., 31: 239-246.

De Blas J.C., Carabaño R. 1996. A review on the energy value of sugar beet pulp for rabbits. World Rabbit Sci., 4: 33-36.

EGRAN 2001. Technical note: attempts to harmonize chemical analyses of food and faeces, for rabbit feed evaluation. World Rabbit Sci., 9: $57-64$

FEDNA 2003. Tablas FEDNA de composición y valor nutritivo de alimentos para la formulación de piensos compuestos $\left(2^{a}\right.$ ed.). In: De Blas J.C., Mateos G.G., Garcia-Rebollar P. (ed.) Fundación Española para el Desarrollo de la Nutrición Animal (FEDNA), Madrid, España.
Fernández-Carmona J., Cervera C., Blas E. 1996. Prediction of the energy value of rabbit feeds varying widely in fibre content. Anim. Feed Sci. Technol., 64: 61-75.

Fraga M.J., Pérez De Ayala P., Carabaño R., De Blas J. C. 1991. Effect of type of fibre on the rate of passage and on the contribution of soft feces to nutrient intake of finishing rabbits nutrient intake of finishing rabbits. J. Anim. Sci., 69: 1566-1574.

Gidenne T., 2000. Recent advances and perspectives in rabbit nutrition: Emphasis on fibre requirements. World Rabbit Sci., 8: 23-32.

Gidenne T., 2003. Fibres in rabbit feeding for digestive troubles prevention: respective role of low-digested and digestible fibre. Livest. Prod. Sci., 81: 105-117.

Gidenne T., Perez J.M. 1994. Apports de lignines et alimentation du lapin en croissance. I. Conséquences sur la digestion et le transit. Ann. Zootech., 43: 313-322.

Gidenne T., Arveux P., Madec O. 2001. The effect of the quality of dietary lignocellulose on digestion, zootechnical performance and health of the growing rabbit. Anim. Sci., 73: 97-104.

INRA. 2004. Tables de composition et de valeur nutritive des matières premières destinées aux animaux d'élevage: porc, volailles, bovins, ovins, caprins, lapins, chevaux, poissons. In: Sauvant D., Perez 
J.M., Tran G. (eds), 2ème Edition revue et corrigée. INRA Editions, Paris, 301p.

International Standarization Organization. 1998. Animal feeding stuffs, animal products, and faeces or urine - Determination of gross calorific value. Bomb calorimeter method. Norme international ISO 9831. Available at: http://www.iso.org.

International Standarization Organization. 1999. Animal feeding stuffs. Determination of moisture and other volatile matter content. Norme international ISO 6496. Available at: http://www.iso.org.

International Standarization Organization. 2002. Animal feeding stuffs. Determination of crude ash. Norme international ISO 5984. Available at: http://www.iso.org.

International Standarization Organization. 2006. Animal feeding stuffs. Determination of amylase-treated neutral detergent fibre content (aNDF). Norme international ISO 16472. Available at: http://www. iso.org.

International Standarization Organization. 2008. Animal feeding stuffs. Determination of acid detergent fibre (ADF) and acid detergent lignin (ADL) contents. Norme international ISO 13906. Available at: http://www.iso.org.

International Standarization Organization. 2009. Food products. Determination of the total nitrogen content by combustion according to the Dumas principle and calculation of the crude protein content. Part 2: Cereals, pulses and milled cereal products. Norme international ISO 16634-2. Available at: http://www.iso. org.

Lakabi-Ioualitene D., Lounaouci-Ouyed G., Berchiche M., Lebas F., Fortun-Lamothe L. 2008. The effects of the complete replacement of barley and soybean meal with hard wheat by-products on diet digestibility, growth and slaughter traits of a local Algerian rabbit population. World Rabbit Sci., 16: 99-106.

Lebas F. 2004. Reflections on rabbit nutrition with a special emphasis on feed ingredients utilization. In Proc.: $8^{\text {th }}$ World Rabbit Congress, 7-10 September, 2004. Puebla, Mexico. 686-736.

Lebas F., Goby J.P.,2005. Valeur nutritive de la luzerne déshydratée à basse température chez le lapin en croissance. Première approche., $11^{\text {eme }}$ Journées de la Recherche Cunicole, Paris. 201-204.

Maertens L., De Groote G. 1984. Digestibility and digestible energy content of a number of feedstuffs for rabbits. In Proc.: $3^{\text {rd }}$ World Rabbit Congress, 4-8 April, 1984. Rome, Italy. 244-251

Maertens L., Perez J.M., Villamide M., Cervera C., Gidenne T., Xiccato G. 2002. Nutritive value of raw materials for rabbits: EGRAN tables 2002. World Rabbit Sci., 10: 157-166

Magnier L. 1991. Utilisation des sous-produits de la vigne dans l'alimentation animale. Options Méditerranéennes. Série Séminaires, 16: 89-99.

Martínez J., Fernández J. 1980. Composicion, digestibilidad, valor nutritivo y relaciones entre ambos de diversos piensos para conejos. In Proc.: $2^{\text {nd }}$ World Rabbit Congress, 16-18 April, 1980. Barcelona, Spain. 214-223.
Motta Ferreira W., Fraga M.J., Carabaño R. 1996. Inclusion of grape pomace, in substitution for alfalfa hay, in diets for growing rabbits. Anim. Sci., 63: 167-174.

Nicodemus N., Carabaño R., García J., Méndez J., De Blas J.C. 1999. Performance response of lactating and growing rabbits to dietary lignin content. Anim. Feed Sci. Technol., 80: 43-54.

Parigi-Bini R., Chiericato G. M. 1980. Utilization of grape marc by growing rabbits. In Proc.: $2^{\text {nd }}$ World Rabbit Congress, 16-18 April, 1980. Barcelona, Spain. 204-213.

Pérez de Ayala P., Fraga M.J., Carabaño R., De Blas J.C. 1991. Effect of fiber source on diet digestibility and growth in fattening rabbits. $J$. Appl. Rabbit Res., 14: 159-165.

Perez J.M., Lebas F., Gidenne T., Maertens L., Xiccato G., ParigiBini R., Dalle Zotte A., Cossu M.E., Carazzolo A., Villamide M.J., Carabaño R., Fraga M.J., Ramos M.A., Cervera C., Blas E., Fernàndez-Carmona J., Falcao E Cunha L., Bengala Freire J. 1995. European reference method for in-vivo determination of diet digestibility in rabbits. World Rabbit Sci., 3: 41-43.

Schurg W.A., Reed J.P., Reid B.L. 1980. Utilization of various fruit pomace products by growing rabbits. Nutr. Rep. Int., 21: 55-62.

Van Soest P.J., Robertson J.B., Lewis B.A. 1991. Methods for dietary fiber, neutral detergent fiber, and non starch polysaccharides in relation to animal nutrition. J. Dairy Sci., 74: 3583-3597.

Villamide M.J. 1996. Methods of energy evaluation of feed ingredients for rabbits and their accuracy. Anim. Feed Sci. Technol., 57: 211223.

Villamide M.J., Maertens L., Cervera C., Perez J.M., Xiccato G. 2001. A critical approach of the calculation procedures to be used in digestibility determination of feed ingredients for rabbits. World Rabbit Sci., 9: 19-26.

Villamide M.J., García J., Cervera C., Blas E., Maertens L., Perez J.M. 2003. Comparison among methods of nutritional evaluation of dietary ingredients for rabbits. Anim. Feed Sci. Technol., 109: 195-207.

Waghom G.C., Uyatt M.J., John A., Fisher M.T. 1987. The effect of condensed tannins on the site of digestion of amino acids and other nutrients in sheep fed on Lotus corniculatus L. Br. J. Nutr., 57:115.

Zerrouki N., Bolet G., Berchiche M., Lebas F. 2005. Evaluation of breeding performance of a local Algerian rabbit population raised in the Tizi-Ouzou area (Kabylia). World Rabbit Sci., 13: 29-37.

Zerrouki N., Kadi S.A., Lebas F., Bolet G. 2007. Characterisation of a kabylian population of rabbits in Algeria: birth to weaning growth performance. World Rabbit Sci., 15: 111-114. 